\title{
THE EFFECT OF COMPOST MADE WITH SEWAGE SLUDGE ON HEAVY METAL CONTENT IN SOIL AND IN LOLIUM MULTIFLORUM LAM.
}

\author{
Elżbieta Malinowska' \\ 1 Department of Grassland and Green Areas Creation, Siedlce University of Natural Sciences and Humanities, \\ Faculty of Natural Science, Institute of Agronomy, 08-110 Siedlce, Poland, e-mail: malinowskae@uph.edu.pl
}

Received: 2016.03.02 Accepted: 2016.06.01 Published: 2016.07.01

\begin{abstract}
The aim of this paper is to assess the effects of different doses of sewage sludge compost mixed with wheat straw on heavy metal content in Italian ryegrass and in soil. A two year experiment with the Italian ryegrass was set up in autumn 2012. The experimental design consisted of a control plot, a plot with NPK fertiliser and three plots with three different doses of municipal sewage sludge compost $(5,10$ and 15 $\mathrm{Mg}$ of fresh matter $\left.\cdot \mathrm{ha}^{-1}\right)$. Those different compost doses contained the amounts of Nitrogen equivalent to 60,120 and $180 \mathrm{~kg} \cdot \mathrm{N} \cdot \mathrm{ha}^{-1}$. The two lower doses of compost were supplemented with nitrogen fertiliser so that the amount of this chemical element introduced to the soil of all plots with compost stood at $180 \mathrm{~kg} \cdot \mathrm{ha}^{-1}$. During 2013 and 2014 seasons the grass was cut three times a year after about a 30-day growing period. After dry mineralisation, the content of $\mathrm{Zn}, \mathrm{Cu}, \mathrm{Ni}, \mathrm{Pb}$ and $\mathrm{Cd}$ in the plant samples was measured with the ICP-AES method. The fertilisers applied significantly diversified the content of chemical elements in the grass and in the soil. The highest dose of compost resulted in the highest concentration of $\mathrm{Zn}, \mathrm{Cu}$ and $\mathrm{Cd}$ in the grass while the highest concentration of $\mathrm{Ni}$ and $\mathrm{Pb}$ was in the soil and the grass from the plot where the mid dose of compost had been applied. Cadmium concentration in the soil was the highest in the plot where the mid dose was applied. The experiment proved that compost made with sewage sludge and wheat straw is beneficial for plants.
\end{abstract}

Keywords: heavy metals, compost, Lolium multiflorum, soil

\section{INTRODUCTION}

It seems that because of economic growth, rising standard of living and legal restrictions the amount of waste will continue to rise in the future. Now when European Union member states have agreed to adhere to regulations on hazardous waste treatment, attempts are being made to find the best ways of their storage and disposal [Ministry of Economy Regulation of 2007, Directive 2008, Waste Management Act of 2012]. High prices of mineral fertilisers, the falling number of farm animals as well as the falling amount of manure are the reason why organic waste is used in agriculture. According to many publications [Speir et al. 2003, Skowrońska 2005, Harrison et al. 2006, Debosz et al. 2012] sewage sludge application to agricultural land contributes to rising amounts of nutrient in soil. Sewage sludge contains a high amount of organic substances and nutrients but also macroelements and microelements [Malinowska et al. 2015]. However, it also contains a high amount of heavy metals, most of them being accumulated in plants [Behel et al. 1983, Álvarez et al. 2002, Kalembasa, Malinowska 2013]. That is why the rising use of sewage sludge or compost made with it should be closely monitored in the soil-plant system [Shrivastava, Banerjee 2004, Yürük, Bozkurt 2006].

The aim of this paper is to assess the effect of different doses of compost made with sewage sludge and wheat straw on heavy metal content in soil and in Italian ryegrass. 


\section{MATERIALS AND METHODS}

The experiment was carried out at the experimental station of the University of Natural Sciences and Humanities in Siedlce (52 $\left.17^{\circ} \mathrm{N}, 22^{\circ} 28^{\prime} \mathrm{E}\right)$. Loam soil, with neutral $\mathrm{pH}_{\mathrm{KCl}}$ of 6.75 , containing $37.0 \mathrm{~g} \cdot \mathrm{kg}^{-1}$ of organic carbon and $1.75 \mathrm{~g} \cdot \mathrm{kg}^{-1}$ of total nitrogen, was taken from the plough layer $(0-25 \mathrm{~cm})$. The average concentration of available phosphorus and potassium determined with the Egner- Rhiem method stood at $39.9 \mathrm{mg} \cdot \mathrm{kg}^{-1}$ and $128 \mathrm{mg} \cdot \mathrm{kg}^{-1}$, respectively. Before the experiment was set up, the total amount of heavy metals in the soil was measured and it was as follows $\left(\mathrm{mg} \cdot \mathrm{kg}^{-1}\right)$ : $\mathrm{Pb}$ - 5.03; $\mathrm{Cd}-0.550 ; \mathrm{Cr}-3.09 ; \mathrm{Cu}-3.20 ; \mathrm{Zn}$ -16.56 ; $\mathrm{Ni}-2.96$. Those results were lower than the limits for municipal sewage sludge applied to light soil imposed by the Minister of the Environment Regulation of 2010. The concentration of some other chemical elements was as follows $\left(\mathrm{g} \cdot \mathrm{kg}^{-1}\right): \mathrm{P}-1.05 ; \mathrm{K}-1.00 ; \mathrm{Ca}-2.40 ; \mathrm{Mg}-1.25$; $\mathrm{S}-0.508 ; \mathrm{Na}-0.312$. The Kroto variety of Italian ryegrass was used in the randomised experiment set up in the autumn of 2012 and replicated three times. The experimental area was divided into the following $2.5 \mathrm{~m}^{2}$ plots: control plot with no fertilisers, a plot with NPK fertilisers applied with the ratio of 1:0.3:0.8 and plots with three different doses of compost based on sewage sludge: 15,10 and $5 \mathrm{Mg} \cdot \mathrm{ha}^{-1}$ of fresh matter, each containing the amount of nitrogen equivalent to 180,120 and 60 $\mathrm{kg} \cdot \mathrm{N} \cdot \mathrm{ha}^{-1}$, respectively. Nitrogen fertilisers were applied three times a year: in early spring before the growing season, and after the first and second cut, while phosphorus and potassium fertilisers were used only once, before sowing. With the application of ammonium sulphate the amount of nitrogen applied was supplemented to $180 \mathrm{~kg} \cdot \mathrm{ha}^{-1}$ on those plots where the rate of nitrogen introduced with the compost was lower than that. We use the following indications: I dose of compost $-15 \mathrm{Mg} \cdot \mathrm{ha}^{-1}+\mathrm{N}_{0}$, II dose of compost $-10 \mathrm{Mg} \cdot \mathrm{ha}^{-1}+\mathrm{N}_{60}$, III dose of

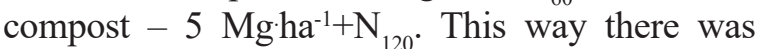
the same amount of nitrogen applied to each plot. The same kinds of inorganic fertilisers were used each year. As said above, the compost contained municipal sewage sludge and $15 \%$ of wheat straw (in relation to dry mass), with the composting process lasting six months. The compost obtained this way was of neutral $\mathrm{pH}$ (Table 1). Like in the case of soil, the total concentration of heavy metals in the compost did not exceed the limits of Fertilisers and Fertilisation Act of 10th July 2007 and Waste Management Act of 2012.

In each growing season of the 2013 and 2014 the grass was cut three times every 30 days, on average. After each cut grass samples were taken and total concentration of $\mathrm{Zn}, \mathrm{Cu}, \mathrm{Ni}, \mathrm{Pb}$ and $\mathrm{Cd}$ was measured with the ICP - AES method, after dry mineralisation in a muffle furnace at the temperature of $450{ }^{\circ} \mathrm{C}$. Then, $5 \mathrm{ml}$ of hydrochloric acid solution (1:1) was added and the porcelain crucible was put into a sand bath to decompose carbonates and to isolate silica. Next, the contents of the crucible, after adding $10 \mathrm{ml}$ of $10 \%$ of hydrochloric acid, were put into a $100 \mathrm{ml}$ conic flask. Additionally, after each year of the experiment soil samples were taken and heavy metal content was determined with the ICP-AES method.

The results were processed statistically to analyse means with the analysis of variance (using the Statistica programme, Version 10.0 StatSoft). Tukey's test was used to calculate the $\mathrm{LSD}_{0.05}$ value.

\section{RESULTS AND DISCUSSION}

The average concentration of zinc in the biomass of Italian ryegrass was $59.05 \mathrm{~g} \cdot \mathrm{kg}^{-1}$ D.M. and was significantly differentiated under the influence of experimental factors and their interaction (Table 2). Zinc concentration in fodder should range from 50 to $100 \mathrm{mg} \mathrm{Zn} \cdot \mathrm{kg}^{-1}$ D.M. [Regulation 2007] and, according to Bednarek et al. [2008], the average content of zinc in noncontaminated plants ranges from 10 to $70 \mathrm{mg} \cdot \mathrm{kg}^{-1}$ D.M. In the present experiment zinc concentration did not exceed $100 \mathrm{mg} \cdot \mathrm{kg}^{-1} \mathrm{DM}$. The highest amount of zinc (mean of 2 years) was found in the biomass of the first cutting $\left(60.63 \mathrm{mg} \cdot \mathrm{kg}^{-1}\right.$ D.M.), and the lowest in the biomass of the third cut-

Table 1. Physico-chemical characteristics of the compost made with sewage sludge

\begin{tabular}{|c|c|c|c|c|c|c|c|c|c|c|c|c|c|c|c|}
\hline $\mathrm{pH}$ & $\mathrm{DM}$ & $\begin{array}{c}\text { Organic } \\
\text { matter }\end{array}$ & $\mathrm{N}_{\text {tot }}$ & $\mathrm{C}_{\text {org }}$ & $\mathrm{Pb}$ & $\mathrm{Cd}$ & $\mathrm{Ni}$ & $\mathrm{Zn}$ & $\mathrm{Cu}$ & $\mathrm{Cr}$ & $\mathrm{Co}$ & $\mathrm{Hg}$ & $\mathrm{Fe}$ & $\mathrm{Mn}$ & $\mathrm{Mo}$ \\
\hline & $\%$ & $\%$ s.m. & \multicolumn{10}{|c|}{$\mathrm{g} \cdot \mathrm{kg}^{-1}$} & \multicolumn{10}{|c|}{$\mathrm{mg}^{-1} \mathrm{~kg}^{-1}$} \\
\hline 6.8 & 27 & 51 & 45.0 & 352 & 72.3 & 0.55 & 2.96 & 879.0 & 85.4 & 24.1 & 2.12 & 0.99 & 6541 & 311 & 2.08 \\
\hline
\end{tabular}


Table 2. Total zinc concentration ( $\mathrm{mg} \cdot \mathrm{kg}^{-1} \mathrm{D}$.M.) in Italian ryegrass

\begin{tabular}{|c|c|c|c|c|c|c|}
\hline \multirow{2}{*}{ Fertilization variants } & \multicolumn{3}{|c|}{ Cuts - means of 2 years } & \multicolumn{2}{|c|}{ Years - means of 3 cuts } & \multirow{2}{*}{$\begin{array}{c}\text { Means of } \\
\text { years }\end{array}$} \\
\hline & I & II & III & 2013 & 2014 & \\
\hline Control object & 31.23 & 30.29 & 29.98 & 30.10 & 30.90 & 30.50 \\
\hline NPK & 33.01 & 30.14 & 30.99 & 32.96 & 29.80 & 31.38 \\
\hline I dose $+\mathrm{N}_{0}$ & 94.14 & 92.38 & 90.12 & 93.55 & 90.88 & 92.21 \\
\hline II dose $+\mathrm{N}_{60}$ & 78.21 & 69.09 & 73.65 & 76.09 & 71.21 & 73.65 \\
\hline III dose $+\mathrm{N}_{120}$ & 66.57 & 70.12 & 65.89 & 71.67 & 63.38 & 67.53 \\
\hline Mean & 60.63 & 58.40 & 58.13 & 60.88 & 57.23 & 59.05 \\
\hline
\end{tabular}

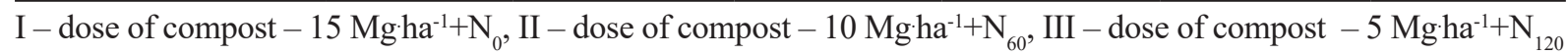

ting (58.13 $\mathrm{mg} \cdot \mathrm{kg}^{-1}$ D.M.). Analysing the effects of different compost doses on the content of this chemical element it was found that the highest dose of compost resulted in threefold increase in the amount of zinc when compared to the control plot and the plot with mineral fertiliser NPK. The falling amount of this metal in the grass of the second and third cutting means that zinc introduced with municipal waste quickly changes to soluble forms [Jakubus, Czekała 2001, Czekała et al. 2012]. Balcer, Wołoszyk [2012] found zinc concentration to be much lower in the biomass of Festulolium fertilised with compost made with biodegradable waste.

Copper concentration in Italian ryegrass was dependent on the dose of fertilisers and on the cutting (Table 3). The highest amount of this metals was found in the grass of the first cutting ( 8.38 $\mathrm{mg} \cdot \mathrm{kg}^{-1}$ D.M.) while in the grass of the second cutting the amount of copper was $11.2 \%$, lower than in the first one. In turn in the grass of the third cutting it was 5.7\% lower than in the grass of the second cutting. The average copper concentration out of all years and cuttings was 7.90 $\mathrm{mg} \cdot \mathrm{kg}^{-1}$ D.M.. According to Baran et al. [2007] copper concentration in the fodder grass should ranged from 7.1 to $10 \mathrm{mg} \cdot \mathrm{kg}^{-1}$ D.M.. The highest copper concentration was in grass with the highest dose of compost (on average $9.20 \mathrm{mg} \cdot \mathrm{kg}^{-1}$ ), and the lowest in the control plot and in the plot with NPK fertiliser (5.91 and $7.58 \mathrm{mg} \cdot \mathrm{kg}^{-1}$, respectively). The average copper concentration in grass is $5.5 \mathrm{mg} \cdot \mathrm{kg}^{-1}$, in non-contaminated areas while in the areas with copper processing industry it is $12.25 \mathrm{mg} \cdot \mathrm{kg}^{-1}$ [Rosada 2007]. According to Framework Guidelines for Agriculture [1993] the concentration of this metal should not exceed $25 \mathrm{mg} \cdot \mathrm{kg}^{-1}$.

The total concentration of nickel in the biomass of Italian ryegrass was $2.32 \mathrm{mg} \cdot \mathrm{kg}^{-1}$ and was significantly dependent on fertilisation and cutting (Table 4). Like in the case of copper, nickel concentration did not differ significantly by year. The highest concentration of nickel was in ryegrass of the first cutting. In the second and third cuttings the concentration of this metal was lower than in the first one, $16.3 \%$ and $19.7 \%$, respectively. The mid dose of compost $\left(10 \mathrm{Mg} \mathrm{ha}^{-1}\right)$

Table 3. Total copper concentration ( $\left.\mathrm{mg} \cdot \mathrm{kg}^{-1} \mathrm{D} . \mathrm{M}.\right)$ in Italian ryegrass

\begin{tabular}{|c|c|c|c|c|c|c|}
\hline \multirow{2}{*}{ Fertilization variants } & \multicolumn{3}{|c|}{ Cuts - means of 2 years } & \multicolumn{2}{|c|}{ Years - means of 3 cuts } & \multirow{2}{*}{$\begin{array}{c}\text { Means of } \\
\text { years }\end{array}$} \\
\hline & I & II & III & 2013 & 2014 & \\
\hline Control object & 6.55 & 5.17 & 6.01 & 5.97 & 5.85 & 5.91 \\
\hline NPK & 8.10 & 7.08 & 7.56 & 7.89 & 7.27 & 7.58 \\
\hline I dose $+\mathrm{N}_{0}$ & 9.78 & 8.70 & 9.11 & 8.99 & 9.41 & 9.20 \\
\hline Il dose $+\mathrm{N}_{60}$ & 9.01 & 9.26 & 8.47 & 8.71 & 9.12 & 8.91 \\
\hline III dose $+\mathrm{N}_{120}$ & 8.45 & 7.01 & 8.30 & 8.01 & 7.83 & 7.92 \\
\hline Mean & 8.38 & 7.44 & 7.89 & 7.91 & 7.90 & 7.90 \\
\hline
\end{tabular}

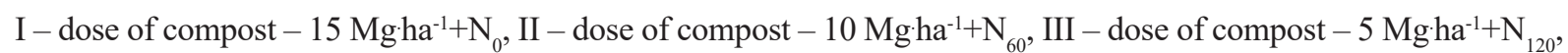
n.s. - not significant difference 
Table 4. Total nickel concentration ( $\mathrm{mg} \cdot \mathrm{kg}^{-1} \mathrm{D} . \mathrm{M}$.) in Italian ryegrass

\begin{tabular}{|c|c|c|c|c|c|c|}
\hline \multirow{2}{*}{ Fertilization variants } & \multicolumn{3}{|c|}{ Cuts - means of 2 years } & \multicolumn{2}{|c|}{ Years - means of 3 cuts } & \multirow{2}{*}{$\begin{array}{c}\text { Means of } \\
\text { years }\end{array}$} \\
\hline & I & II & III & 2013 & 2014 & \\
\hline Control object & 1.81 & 1.54 & 1.68 & 1.81 & 1.54 & 1.68 \\
\hline NPK & 1.97 & 1.60 & 1.74 & 2.04 & 1.50 & 1.77 \\
\hline I dose $+\mathrm{N}_{0}$ & 2.70 & 2.64 & 2.08 & 2.35 & 2.59 & 2.47 \\
\hline II dose $+\mathrm{N}_{60}$ & 3.74 & 2.41 & 2.89 & 2.71 & 3.32 & 3.01 \\
\hline III dose $+\mathrm{N}_{120}$ & 3.01 & 2.87 & 2.19 & 2.47 & 2.91 & 2.69 \\
\hline Mean & 2.64 & 2,21 & 2.12 & 2.28 & 2.37 & 2.32 \\
\hline
\end{tabular}

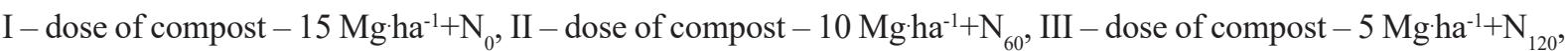
n.s. - not significant difference

resulted in an increase in nickel concentration in Italian ryegrass by $44.2 \%$ compared to the control plot and by $41.2 \%$ compared to the plot with NPK fertiliser.

According to Kabata-Pendias, Pendias [1999] lead concentration in plants from non-polluted areas should not exceed $3 \mathrm{mg} \cdot \mathrm{kg}^{-1}$. In the present experiment concentration of this metal ranged from 0.634 to $2.22 \mathrm{mg} \cdot \mathrm{kg}^{-1}$, being on average 1.22 $\mathrm{mg} \cdot \mathrm{kg}^{-1}$ (Table 5). In the grass of the firs cutting there was more lead than in the grass of the second cutting. There was also significantly more of this metal in the second year than in the first year. There was twice as much lead in the grass from the plot with the mid dose of compost applied as in the grass from the plot with NPK fertiliser.

The total concentration of cadmium was $0.411 \mathrm{mg} \cdot \mathrm{kg}^{-1}$ (Table 6) and it was lower than the limit of $1 \mathrm{mg} \cdot \mathrm{kg}^{-1}$ for this metal content in fodder plants [Kabata-Pendias, Pendias 1999]. Symanowicz [2005] and Kalembasa, Malinowska [2010] provide a similar content of cadmium in Italian ryegrass grown on soil with sewage sludge compost applied. The highest amount of cadmi- um was in the grass of the first cutting with the lowest amount in the grass of the second cutting. The concentration of this metal in the biomass was dependent on fertilisation and the year. There was a significant decrease of cadmium concentration in the grass in the second year, when it was $10.1 \%$ lower, on average, compared to the first year. The highest concentration of cadmium in Italian ryegrass $\left(0.526 \mathrm{mg} \cdot \mathrm{kg}^{-1}\right)$ was noted in the plot with the highest dose of compost, while the lowest in the plot with the lowest dose of compost and in the control plot, 0.320 and $0.366 \mathrm{mg} \cdot \mathrm{kg}^{-1}$, respectively.

According to many publications heavy metal accumulation by plants is not always related to their concentration in the soil [Czekała et al. 2012]. What determines it is soil conditions, plant species but also a potential of a given element to be released from stable forms [Pavlikova et al. 2007]. Kabata-Pendias at al. [1993] put the limits of heavy metals in fodder plants in the following order: $<100 \mathrm{mg} \mathrm{Zn}<30 \mathrm{mg} \mathrm{Cu}<20 \mathrm{mg} \mathrm{Cr}<50 \mathrm{mg}$ $\mathrm{Ni}<10 \mathrm{mg} \mathrm{Pb}$ and $<0.5 \mathrm{mg} \mathrm{Cd} \cdot \mathrm{kg}^{-1}$ D.M. Biomass with heavy metal content exceeding those limits

Table 5. Total lead concentration ( $\mathrm{mg} \cdot \mathrm{kg}^{-1} \mathrm{D}$.M.) in Italian ryegrass

\begin{tabular}{|c|c|c|c|c|c|c|}
\hline \multirow{2}{*}{ Fertilization variants } & \multicolumn{3}{|c|}{ Cuts - means of 2 years } & \multicolumn{2}{|c|}{ Years - means of 3 cuts } & \multirow{2}{*}{$\begin{array}{c}\text { Means of } \\
\text { years }\end{array}$} \\
\hline & 1 & II & III & 2013 & 2014 & \\
\hline Control object & 0.981 & 0.748 & 0.779 & 0.729 & 0.942 & 0.836 \\
\hline NPK & 0.654 & $0.8,01$ & 0.747 & 0.634 & 0.834 & 0.734 \\
\hline I dose $+\mathrm{N}_{0}$ & 1.11 & 1.54 & 1.02 & 1.12 & 1.33 & 1.22 \\
\hline II dose $+\mathrm{N}_{60}$ & 2.22 & 1.78 & 1.47 & 1.66 & 1.99 & 1.82 \\
\hline III dose $+\mathrm{N}_{120}$ & 1.88 & 1.62 & 1.01 & 1.39 & 1.62 & 1.50 \\
\hline Mean & 1.37 & 1.30 & 1.01 & 1.11 & 1.34 & 1.22 \\
\hline
\end{tabular}

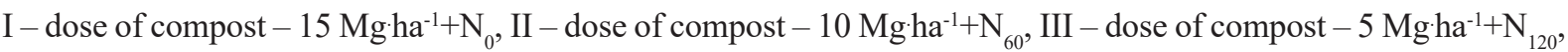
n.s. - not significant difference 
Table 6. Total cadmium concentration ( $\mathrm{mg} \cdot \mathrm{kg}^{-1} \mathrm{D}$.M.) in Italian ryegrass

\begin{tabular}{|c|c|c|c|c|c|c|}
\hline \multirow{2}{*}{ Fertilization variants } & \multicolumn{3}{|c|}{ Cuts - means of 2 years } & \multicolumn{2}{|c|}{ Years - means of 3 cuts } & \multirow{2}{*}{$\begin{array}{c}\text { Mean of } \\
\text { years }\end{array}$} \\
\hline & I & II & III & 2013 & 2014 & \\
\hline Control object & 0.430 & 0.320 & 0.348 & 0.405 & 0.327 & 0.366 \\
\hline NPK & 0.320 & 0.360 & 0.417 & 0.412 & 0.332 & 0.372 \\
\hline I dose $+\mathrm{N}_{0}$ & 0.540 & 0.501 & 0.536 & 0.563 & 0.489 & 0.526 \\
\hline Il dose $+\mathrm{N}_{60}$ & 0.499 & 0.422 & 0.489 & 0.489 & 0.450 & 0.470 \\
\hline III dose $+\mathrm{N}_{120}$ & 0.322 & 0.356 & 0.252 & 0.309 & 0.331 & 0.320 \\
\hline Mean & 0.422 & 0.392 & 0.418 & 0.436 & 0.392 & 0.411 \\
\hline
\end{tabular}

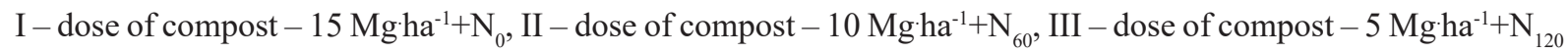

should not be used to feed animals but it should be combusted or used to produce compost.

The content of $\mathrm{Zn}, \mathrm{Cu}, \mathrm{Ni}$ and $\mathrm{Pb}$ in the soil was significantly diversified under the influence of experimental factors (Table 7). Fertilisation significantly diversified cadmium content. With the exception of zinc and lead the total amount of heavy metals in the soil was similar in the control plot and in the one with NPK fertiliser. Compost application, in particular at the higher doses of 15 and $10 \mathrm{Mg} \cdot \mathrm{ha}^{-1}$, increased zinc concentration in the soil three times while $\mathrm{Ni}, \mathrm{Pb}$ and $\mathrm{Cd}$ concentration was increased two times. There was also significantly more lead and a little more cadmium in the first year than in the second. Concentration of the other heavy metals was significantly higher in the second year than in the first year. Throughout the experiment the average concentration of heavy metals from all plots can be put in the following order $\left(\mathrm{mg} \cdot \mathrm{kg}^{-1}\right): \mathrm{Zn}(36.02)<\mathrm{Pb}$ (6.67) $<\mathrm{Cu}(6.28)<\mathrm{Ni}(5.15)<\mathrm{Cd}(1.48)$. Balcer and Wołoszyk [2012] found a similar content of copper but a much lower content of zinc in soil in the second year after compost made with sewage sludge was applied. The above mentioned authors say that, compared to the control, compost made with $70 \%$ of sewage sludge resulted in a higher content of microelements in plants and in soils.

Table 7. Heavy metal concentration ( $\mathrm{mg} \cdot \mathrm{kg}^{-1} \mathrm{D}$.M.) in the soil in the first and second year of the experiment

\begin{tabular}{|c|c|c|c|c|c|c|}
\hline $\begin{array}{c}\text { Fertilization } \\
\text { variants }\end{array}$ & Years & $\mathrm{Zn}$ & $\mathrm{Cu}$ & $\mathrm{Ni}$ & $\mathrm{Pb}$ & $\mathrm{Cd}$ \\
\hline \multirow{3}{*}{ Control object } & 2013 & 15.12 & 5.66 & 3.25 & 5.14 & 1.28 \\
\hline & 2014 & 20.71 & 5.11 & 2.63 & 4.12 & 0.557 \\
\hline & Mean & 17.92 & 5.38 & 2.94 & 4.63 & 0.919 \\
\hline \multirow{3}{*}{ NPK } & 2013 & 11.20 & 4.12 & 2.23 & 6.10 & 0.987 \\
\hline & 2014 & 12.36 & 5.89 & 2.96 & 5.07 & 1.08 \\
\hline & Mean & 11.78 & 5.01 & 2.60 & 5,59 & 1.03 \\
\hline \multirow{3}{*}{ I dose $+\mathrm{N}_{0}$} & 2013 & 55.95 & 8.56 & 5.56 & 7.74 & 1.11 \\
\hline & 2014 & 63.70 & 7.99 & 6.99 & 7.09 & 2.09 \\
\hline & Mean & 59.83 & 8.28 & 6.28 & 7.42 & 1.60 \\
\hline \multirow{3}{*}{ II dose $+\mathrm{N}_{60}$} & 2013 & 51.20 & 7.12 & 7.12 & 8.85 & 2.13 \\
\hline & 2014 & 56.98 & 6.42 & 8.66 & 8.23 & 2.01 \\
\hline & Mean & 54.09 & 6.77 & 7.89 & 8.54 & 2.07 \\
\hline \multirow{3}{*}{ III dose $+\mathrm{N}_{120}$} & 2013 & 32.09 & 5.01 & 6.23 & 7.23 & 1.99 \\
\hline & 2014 & 40.89 & 6.89 & 5.87 & 7.11 & 1.54 \\
\hline & Mean & 36.49 & 5.95 & 6.05 & 7.17 & 1.77 \\
\hline \multicolumn{2}{|l|}{ Mean 2013} & 33.11 & 6.09 & 4.88 & 7.01 & 1.50 \\
\hline \multicolumn{2}{|l|}{ Mean 2014} & 38.92 & 6.46 & 5.42 & 6.32 & 1.46 \\
\hline \multicolumn{2}{|l|}{ Mean } & 36.02 & 6.28 & 5.15 & 6.67 & 1.48 \\
\hline \multicolumn{2}{|c|}{$\begin{array}{l}L_{S S} \text { for: } F \text { - fertilization } \\
Y \text { - years } \\
\text { FXY - interaction } \\
Y X F \text { - interaction }\end{array}$} & $\begin{array}{c}1.06 \\
0.469 \\
1.51 \\
1.05 \\
\end{array}$ & $\begin{array}{l}0.444 \\
0.196 \\
0.628 \\
0.438 \\
\end{array}$ & $\begin{array}{l}0.524 \\
0.231 \\
0.741 \\
0.517 \\
\end{array}$ & $\begin{array}{c}0.649 \\
0.286 \\
\text { n.s. } \\
\text { n.s. } \\
\end{array}$ & $\begin{array}{c}0.201 \\
\text { n.s. } \\
0.284 \\
0.198 \\
\end{array}$ \\
\hline
\end{tabular}

I - dose of compost $-15 \mathrm{Mgha}^{-1}+\mathrm{N}_{0}$, II - dose of compost - $10 \mathrm{Mgha}^{-1}+\mathrm{N}_{60}$, III - dose of compost $-5 \mathrm{Mg}^{-1}+\mathrm{N}_{120}$, n.s. - not significant difference 
Compared to the control, changes of the concentration of heavy metals in the soil varied in all the years of the experiment (Figure 1).

The highest dose of compost did not always resulted in a higher amount of heavy metals in the soil even if there was such a relationship in the case of $\mathrm{Zn}$ and $\mathrm{Cu}$. In turn, a mid dose of compost, supplemented with mineral nitrogen, caused the highest rise of $\mathrm{Ni}$ and $\mathrm{Pb}$ content. Like with $\mathrm{Cd}$, there was a significant increase of the content of those metals in the second year of the experiment.

The use of compost made with sewage sludge led to a rise of the chemical elements content both in plants and in the soil [De Browuere, Smolders 2006, Iżewska 2009, Wołoszyk et al. 2009]. At the same time there was no accumulation of those elements in the soil-plant system [Kabata-Pendias, Pendias 1999]. Madej, Wasiak [2005] point out that nutritional value of sewage sludge is higher than the nutritional value of manure and its use results in higher yields of crops.

\section{CONCLUSIONS}

1. In the grass from the plot where compost made with sewage sludge and wheat straw was applied there was an increase in heavy metal content $(\mathrm{Zn}, \mathrm{Cu}, \mathrm{Ni}, \mathrm{Pb}$ and $\mathrm{Cd}$, as compared to the control plot and to the plot with NPK fertiliser applied.

2. Analysing the effects of different compost doses on heavy metal content it was found that the highest amount of compost $\left(15 \mathrm{Mg} \cdot \mathrm{ha}^{-1}\right)$ resulted in the highest accumulation of $\mathrm{Zn}, \mathrm{Cu}$ and $\mathrm{Cd}$, while the highest amounts of $\mathrm{Ni}$ and $\mathrm{Pb}$ were in the grass from the plot with the mid dose of compost $\left(10 \mathrm{Mg} \cdot \mathrm{ha}^{-1}\right)$.

3. Compared to the first year there was an increase of the amount of $\mathrm{Zn}, \mathrm{Cu}$ and $\mathrm{Ni}$ in the soils in the second year of the experiment.

4. The experiment proved that the effects of compost made with sewage sludge and wheat straw were beneficial for plants.
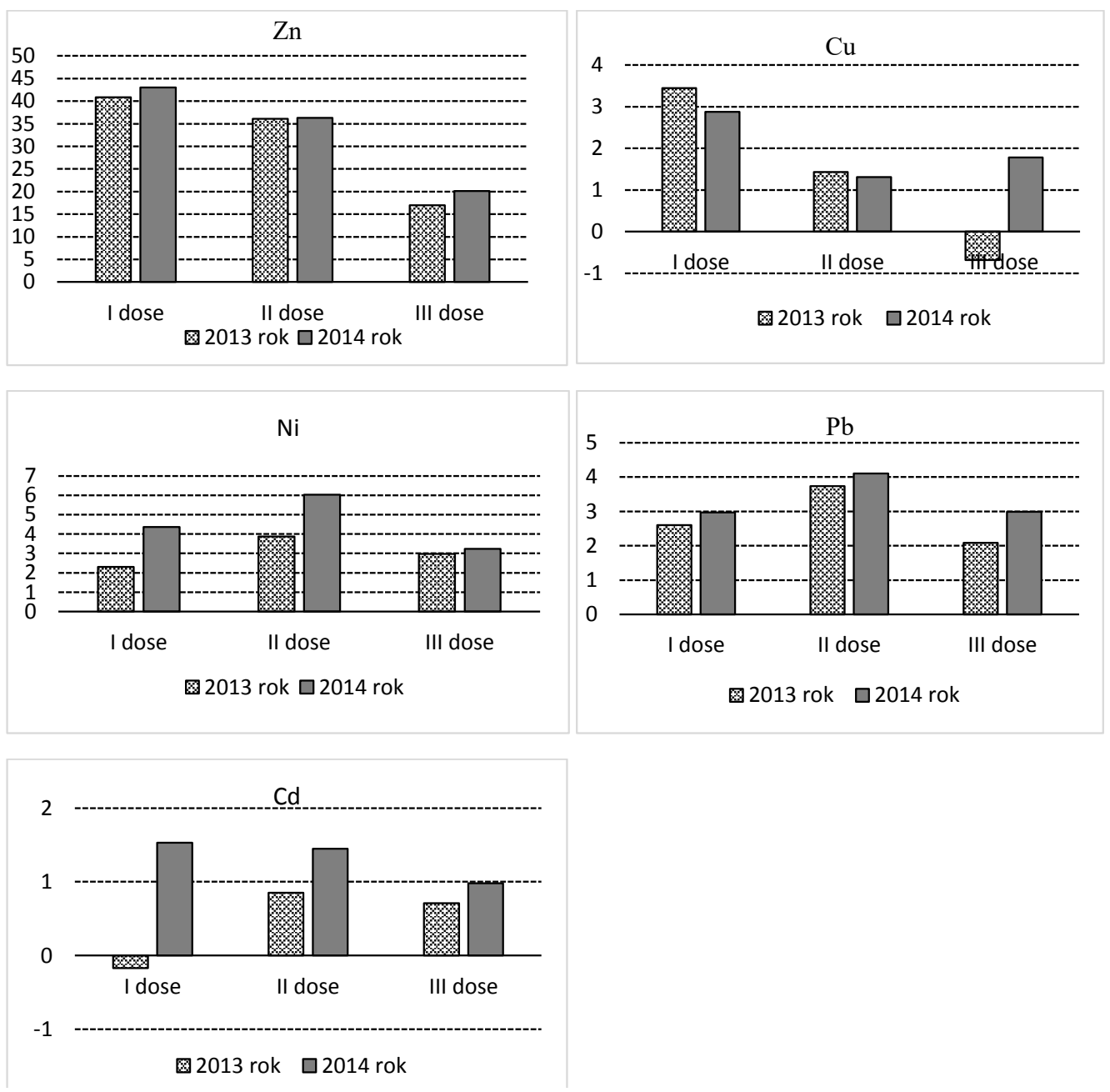

Figure 1. Changes of total concentration of heavy metals in the soil after compost application $\left(\mathrm{mg} \cdot \mathrm{kg}^{-1}\right)$, compared to the control 


\section{REFERENCES}

1. Álvarez A.E., Mochón M.C., Sánchez J.C.J., Rodríguez M.T. 2002. Heavy metal extractable forms in sludge from wastewater treatment plants. Chemosphere, 47 (7), 765-775.

2. Balcer K., Wołoszyk Cz. 2012. Wpływ kompostów $\mathrm{z}$ odpadów biodegradowalnych na kształtowanie zawartości mikroskładników w roślinach i glebie. Zesz. Nauk. UP Wrocław, Rolnictwo CIII, 589, 23-31.

3. Baran A., Spałek I., Jasiewicz Cz. 2007. Zawartość metali ciężkich w roślinach i gruntach przylegających do wybranych stacji paliw w Krakowie. Mat. Krakowskiej Konf. Młodych Uczonych, Kraków, 265-272.

4. Bednarek W., Tkaczyk P., Dresler S. 2008. Zawartość metali ciężkich jako kryterium oceny jakości ziarna pszenicy ozimej. Acta Agroph. 12 (2), 315-326.

5. Behel D., Nelson D.W., Sommers L.E. 1983. Assessment of heavy metals equilibria in sewage sludgetreated soil. J. Environ. Quality, 12, 181-186.

6. Czekała J., Mocek A., Owczarzak W. 2012. Działanie wieloletniego nawożenia osadami ściekowymi na zawartość form rozpuszczalnych cynku i miedzi w glebie. Zesz. Nauk. UP Wrocław, Rolnictwo CIII, 589, 43-50.

7. De Browuere K., Smolders E. 2006. Yield response of crops amended with sewage sludge in the field is more affected by sludge properties than by final soil metal concentration. European J. Soil Sci. 57, 558-567.

8. Debosz K., Petersen S., Kure L., Ambus P. 2012. Evaluating effects of sewage sludge and household composts on soil physical, chemical and microbiological properties. Appl. Soil Ecol. 19, 237-248.

9. Dyrektywa Parlamentu Europejskiego i Rady 2008/98/WE z dnia 19 listopada 2008 r. w sprawie odpadów oraz uchylająca niektóre dyrektywy. Dz.U. UE L 312/3.

10. Harrison E.Z., Oakes S.R., Hysell M., Hay A. 2006. Organic chemicals in sewage sludges. Sci. Tot. Environ. 367, 481-497.

11. Iżewska A. 2009. The impact of manure, municipal sewage sludge and compost prepared from municipal sewage sludge on crop field and content of $\mathrm{Mn}$, $\mathrm{Zn}, \mathrm{Cu}, \mathrm{Ni}, \mathrm{Pb}, \mathrm{Cd}$ in spring rape and spring triticale. J. Elem. 14 (3), 449-456.

12. Jakubus M., Czekała J. 2001. Heavy metal speciation in sewage sludge. Pol. J. Environ. Stud. 10 (4), 245-250.

13. Kabata-Pendias A., Motowicka-Terelak T., Piotrowska M., Terelak H., Witek T. 1993. Ocena stopnia zanieczyszczenia gleb i roślin metalami ciężkimi i siarką. IUNG, Puławy, pp 7-10.

14. Kabata-Pendias A., Pendias H. 1999. Biogeochemistry of trace elements. PWN, Warsaw, pp. 398.

15. Kalembasa D., Malinowska E. 2013. Bioaccumulation of zinc under the influence of sewage sludge and liming and its speciation in soil. Fresenius Environ. Bull. 22 (11a), 3359-3369.
16. Kalembasa S., Malinowska E. 2010. Influence of sewage sludge rates on cadmium content in test plants and its fractions in soil. Pol. J. Environ. Stud. Series of Monographs 2, 91-98.

17. Madej M., Wasiak G. 2005. Terms for using municipal waste and sewage sludge for compost production. Ecol. Chem. Eng. 12 (3), 261-266.

18. Malinowska E., Jankowski K., Wiśniewska-Kadżajan B., Sosnowski J., Kolczarek R. 2015. Effect of different methods of treatment of municipal sewage sludge on their physicochemical properties and their agricultural utilization. J. Ecol. Eng. 16 (2), 76-81.

19. Pavlikova D., Balik J., Tlustoš P. 2007. Effect of cadmium content in soil and crop rotation on cadmium accumulation in plant biomass. Ecol. Chem. Eng. 14 (3-4), 363-369.

20. Ramowe wytyczne dla rolnictwa 1993. Ocena stanu zanieczyszczenia gleb i roślin metalami ciężkimi i siarką. IUNG, Puławy.

21. Rosada J. 2007. Ekologiczne aspekty wykorzystania obszarów objętych oddziaływaniem emisji hut miedzi do upraw rolniczych. Postępy w Ochronie Roślin, (1), 119-127.

22. Rozporządzenie Ministra Gospodarki z dnia 12 czerwca 2007 r. zmieniające rozporządzenie w sprawie kryteriów oraz procedur dopuszczania odpadów do składowania na składowisku odpadów danego typu. Dz.U. z 2007 r. nr 121, poz. 832.

23. Rozporządzenie Ministra Rolnictwa i Rozwoju Wsi z dnia 23 styczna 2007 w sprawie dopuszczalnych zawartości substancji niepożądanych w paszach. Dz.U. 2007, nr 20, poz. 119.

24. Shrivastava S.K., Banerjee D.K. 2004. Speciation of metals in sewage sludge and sludge - amended soils. Water, Air and Soil Pollution, 152, 219-232.

25. Skowrońska M. 2005. Skład frakcyjny glebowej substancji organicznej w warunkach stosowania odpadów organicznych. Zesz. Probl. Post. Nauk Rol. 505, 383-389.

26. Speir T.W., Schaik A.P. Van, Percival H.J., Close M.E., Pang L.P. 2003. Heavy metals in soil, plants and groundwater following high-rate sewage sludge application to land. Water, Air and Soil Pollution, 150 (1-4), 319-358.

27. Symanowicz B. 2005. Wpływ węgli brunatnych, osadów ściekowych oraz ich mieszanin i obornika na zawartość kadmu i ołowiu w podłożu glebowym i życicy wielokwiatowej (Lolium multiflorum Lam.). Acta Sci. Pol., Agricultura, 4 (2), 83-92.

28. Ustawa z dnia 14 grudnia 2012 r. o odpadach (Dz.U. 2013 r. Nr. 62, 888, 1238, poz. 21).

29. Wołoszyk Cz., Iżewska A., Krzywy-Gawrońska E. 2009. Content, uptake and utilization by plants of copper, manganese and zinc from municipal sewage sludge and wheat straw. J. Elem. 14 (3), 593-604.

30. Yürük A., Bozkurt M.A. 2006. Heavy metal accumulation in different organs of plants grown under high sewage sludge doses. Fresenius Environ. Bull. 15 (2), 107-112. 